\title{
Africanized honey bees (Apis mellifera) have low infestation levels of the mite Varroa destructor in different ecological regions in Mexico
}

\author{
C.A. Medina-Flores ${ }^{1}$, E. Guzmán-Novoa ${ }^{2}$, M.M. Hamiduzzaman ${ }^{2}$, \\ C.F. Aréchiga-Flores ${ }^{1}$ and M.A. López-Carlos ${ }^{1}$ \\ ${ }^{1}$ Faculty of Veterinary Medicine and Animal Science, \\ University of Zacatecas, Zacatecas, Mexico \\ ${ }^{2}$ School of Environmental Sciences, University of Guelph, Guelph, \\ Ontario, Canada \\ Corresponding author: E. Guzmán-Novoa \\ E-mail: eguzman@uoguelph.ca
}

Genet. Mol. Res. 13 (3): $7282-7293$ (2014)

Received May 28, 2013

Accepted September 19, 2013

Published February 21, 2014

DOI http://dx.doi.org/10.4238/2014.February.21.10

\begin{abstract}
Honey bee (Apis mellifera) colonies of African and European descent were compared for levels of Varroa destructor infestation in 3 different ecological regions in Mexico. The 300 colonies that were studied were located in subtropical, temperate sub-humid, and temperate dry climates. The morphotype and mitotype of adult bees as well as their rates of infestation by varroa mites were determined. Additionally, the number of combs with brood and covered with bees was recorded for each colony. The highest frequency of colonies that were classified as African-derived was found in the subtropical environment, whereas the lowest occurred in the temperate dry region. Overall, the colonies of African genotype had significantly lower mite infestation rates $(3.5 \pm 0.34 \%)$ than the colonies of European genotype $(4.7 \pm 0.49 \%)$ regardless of the region sampled. Significant effects of genotype and region on Varroa infestation rates were evident, and there were no differences in bee population or capped brood between
\end{abstract}


genotypes. Mite infestation levels were significantly lower in the colonies of the temperate dry region than in the colonies of the other 2 regions. These results are discussed within the context of results from studies that were previously conducted in Brazil. This is the first study that demonstrates the effects of Africanization and ecological environment on $V$. destructor infestation rates in honey bee colonies in North America.

Key words: Apis mellifera; Africanized bees; Varroa destructor; Varroa resistance; Environmental effects; Mexico

\section{INTRODUCTION}

Varroa destructor is a parasitic mite that has become the most serious health problem of the western honey bee, Apis mellifera (Hymenoptera: Apidae) in many countries (De Jong, 1997). There is evidence that this mite is one of the factors associated with the unprecedented loss of honey bee colonies recently experienced in parts of Europe and North America (Guzmán-Novoa et al., 2010; Le Conte et al., 2010). Conversely, studies conducted in Brazil suggest that infestations by Varroa are not a major problem for honey bee colonies in that country, in part apparently because of the natural resistance in Africanized bees to the mite (Page and Guzmán-Novoa, 1997). Additionally, bees of European and African descent differ in their degree of adaptation to tropical and temperate environments (Winston, 1992), which could also help explain why Varroa infestations are relatively low in Brazil. Despite this apparent resistance of Africanized bees to Varroa, if the mite infestation levels are high ( $>5 \%)$, the parasite can severely affect the honey production of their colonies (Arechavaleta-Velasco and Guzmán-Novoa, 2000; Medina-Flores et al., 2011).

Very few studies have attempted to compare honey bee colonies of African and European descent for their resistance to varroa mites in different ecological regions to simultaneously study genotypic and environmental effects on the mite's parasitic levels. In one study of this type, Moretto et al. (1991) sampled Africanized and Italian x Africanized hybrid bee colonies and determined varroa mite infestation rates on adult workers in different regions of Brazil; their results showed that climate and bee type influenced varroa mite infestation rates. Africanized bee colonies, particularly in tropical environments, had lower infestation rates than colonies of hybrid bees. Later, Moretto and Mello Jr. (1999) demonstrated the genotypic nature of the resistance of Africanized bees to Varroa infestation in a study in which Africanized and European workers were co-fostered in common hives. Their results suggest a pre-adaptation of African-derived bees that makes them less susceptible to varroa mite infestations.

In the Africanized areas of North America, no studies with the objective of simultaneously studying both genotypic and environmental effects on Varroa infestations of honey bee colonies have been carried out. In Mexico, Africanized bees were first detected in 1986, and they became well established in all regions of the country 20 years later (Quezada-Euán, 2007; Guzmán-Novoa et al., 2011). There is ample information about the degree and process of Africanization of honey bee colonies in the southeast region of Mexico (Quezada-Euán, 2000; Clarke et al., 2002), but little is known about this process in other areas of the country or in other regions of North America. The presence of $V$. destructor in Mexico is more recent; it 
was found in the Gulf coast in 1992 (Chihu et al., 1992), but it took several years to spread to different regions of the country. Evidently, Varroa has parasitized Africanized bees in Mexico considerably less time than in Brazil. Because of this relatively recent time of exposure and because Africanized bee populations in Mexico have gone through many generations of interbreeding with European populations of bees, it is possible that they might have become less tolerant to the mite than bees in Brazil; thus, their difference in tolerance compared with bees of European descent might not be significant.

Considering the above, studies on the distribution and frequency of African and European bee genotypes and their variation in susceptibility to $V$. destructor infestations in different ecological regions of North America would be very valuable. Therefore, the aim of this study was to determine the frequency of African- and European-derived genotypes of honey bees and their associated levels of varroa mite infestations in 3 different ecological environments in Northern Mexico.

\section{MATERIAL AND METHODS}

\section{Study areas}

Data on colony populations and amount of brood as well as samples of adult worker bees were collected from 300 commercial honey bee colonies that had not been treated against varroa mites or requeened for at least 1 year in the State of Zacatecas, Mexico $\left(22^{\circ} 57^{\prime} \mathrm{N}\right.$, $\left.102^{\circ} 42^{\prime} \mathrm{W}\right)$. The samples were used to determine the African or European ancestry of the bees as well as $V$. destructor infestation levels. The presence of Africanized bees and varroa mites in Zacatecas was first reported in 1991 and 1995, respectively (Guzmán-Novoa et al., 2011). The colonies that were studied were located in 15 municipalities of 3 different ecological regions, and 100 colonies per region were sampled. The relevant climatic and floral characteristics of each region are described below.

\section{Subtropical}

This region is located $600-1200 \mathrm{~m}$ above sea level, has a mean annual precipitation of $850 \mathrm{~mm}$, and its mean annual temperature is $22^{\circ} \mathrm{C}$ (Instituto Nacional de Estadística Geografía e Informática, INEGI, 2001). It is the lowest, warmest, and most humid of the 3 regions studied, and also has more floral resources of beekeeping value than the other 2 regions. There are 2 main nectar flows that occur during spring and fall from deciduous trees and bushes.

\section{Temperate sub-humid}

This region is located $1200-2000 \mathrm{~m}$ above sea level, has a mean annual precipitation of $780 \mathrm{~mm}$, and its average temperature is $18^{\circ} \mathrm{C}$ (INEGI, 2001). This region is intermediate in altitude and temperature between the other 2 regions, and it represents a transition between temperate and subtropical climates. The region has plenty of floral resources that produce 2 main nectar flows that occur during spring and fall from deciduous and sclerophyllous broadleaf trees. 


\section{Temperate dry}

This region is located $1600-2600 \mathrm{~m}$ above sea level, has a mean annual precipitation of $470 \mathrm{~mm}$, and its average temperature is $15^{\circ} \mathrm{C}$ (INEGI, 2001). It is the highest, coldest, and driest of the 3 regions, and it also has fewer floral resources than the other 2 regions. There are 2 main nectar flows that occur during spring and fall from shrubs, cacti, and weeds.

\section{Assessment of colony population and sample collection}

Colonies were assessed and sampled on 2 occasions during May 2010, after the spring honey harvest. At this time of the year, colonies are populated and have brood in all regions. Colony populations were estimated by counting the number of frames covered by bees and those containing capped brood (Delaplane et al., 2013). A frame was counted as 1 unit, only if it was completely covered by bees or had capped brood on at least $50 \%$ of its surface, or fractions of 1 unit were used when partial coverage of the frame was observed. Regarding samples, each of them consisted of approximately 300 adult bees that were collected in a glass jar containing $70 \%$ ethanol from brood nest frames in each hive.

\section{Laboratory procedures}

To diagnose and determine infestation levels by $V$. destructor as per De Jong et al. (1982), the jars with the bees were agitated for $30 \mathrm{~min}$ on a mechanical shaker (Eberbach, Ann Arbor, MI, USA), and the mites that were dislodged from the bees' bodies were strained. The number of bees and mites was counted, and the number of mites per 100 bees was calculated for each sample. This test was performed twice per colony with an interval of 2 weeks between samplings, and the average adult bee infestation rate per colony was calculated.

To determine the morphological type of bees (morphotype), 30 workers per colony were subjected to the Fast Africanized Bee Identification System (FABIS; Sylvester and Rinderer, 1987). Additionally, 5 bees per colony were used to determine their mitochondrial DNA type (mitotype) as per Nielsen et al. (2000). The Varroa infestation and morphometric analyses of the bees were performed at the Veterinary Academic Unit, University of Zacatecas, Mexico. Molecular analyses to determine the mitotype of the bees were done at the School of Environmental Sciences, University of Guelph, Canada.

\section{Statistical analyses}

Colonies were classified according to their bees' morphotype and mitotype for each of the regions that were sampled, and their frequencies were subjected to chi-square tests for comparisons. Data on the percentage of adult bee infestation were square-root-arcsine transformed before subjecting them to analyses of variance, Fisher protected least significant difference, and $t$-tests. Nonparametric tests (Kruskal-Wallis and Mann-Whitney U-tests) were used to analyze data on capped brood and colony population because they were not normalized after transformations. In order to more objectively assess the effect of regions and degree of Africanization of colonies on varroa mite infestation levels, colonies were separately ana- 
lyzed by morphotype, mitotype, or genotype (colonies that in both classifications were either European or African-derived). All statistical analyses were performed with the R Statistical Program (R Development Core Team, Auckland, New Zealand).

\section{RESULTS}

There were significant differences in the frequency of honey bee morphotypes among the 3 study regions $(\mathrm{P}<0.01)$. The highest frequency of colonies with European morphotypes and the lowest with African morphotypes occurred in the temperate dry region. Conversely, the lowest frequency of colonies with European morphotypes and the highest with African morphotypes occurred in the subtropical region (Table 1). Similar results were found for honey bee mitotypes, with significant differences between the temperate dry and the other 2 regions $(\mathrm{P}<0.01$; Table 2). These results indicate a higher degree of Africanization in colonies of the subtropical and temperate sub-humid areas and a lower degree of Africanization in colonies of the temperate dry area.

\begin{tabular}{|c|c|c|c|c|}
\hline Region & European & Africanized & $\chi^{2}$ & $\mathrm{P}$ \\
\hline Subtropical & 13 & 87 & 20.6 & $<0.0001$ \\
\hline Temperate sub-humid & 30 & 70 & 8.6 & 0.0034 \\
\hline Temperate dry & 62 & 38 & 51.2 & $<0.0001$ \\
\hline
\end{tabular}

$\chi^{2}$ and $\mathrm{P}$ values are reported from top to bottom for comparisons between regions as follows: subtropical and temperate sub-humid, temperate sub-humid and temperate dry, and temperate dry and subtropical.

$\begin{aligned} & \text { Table 2. Number of colonies with honey bees of European or African mitotype in three different ecological } \\
& \text { regions of Mexico ( }=100 \text { per region). }\end{aligned}$
\begin{tabular}{lcccc}
\hline Region & European & African & $\chi^{2}$ & $\mathrm{P}$ \\
\hline Subtropical & 70 & 30 & 0.2 & 0.8779 \\
Temperate sub-humid & 69 & 31 & 9.8 & 0.0018 \\
Temperate dry & 88 & 12 & 10.7 & 0.0011 \\
\hline
\end{tabular}

$\chi^{2}$ and $\mathrm{P}$ values are reported from top to bottom for comparisons between regions as follows: subtropical and temperate sub-humid, temperate sub-humid and temperate dry, and temperate dry and subtropical.

V. destructor was found in most colonies in the 3 regions that were sampled. However, the parasite was significantly less prevalent in the temperate dry region than in the subtropical and temperate sub-humid regions $\left(\chi^{2}=12.1, \mathrm{P}<0.001 ; \chi^{2}=4.9, \mathrm{P}<0.05\right.$, respectively), between which no differences in mite prevalence were found $(\mathrm{P}>0.05)$. V. destructor was more prevalent in colonies with European-derived morphotypes and mitotypes regardless of the region sampled. The percentages of colonies with African- or European-derived morphotypes where $V$. destructor was detected in the 3 regions are shown in Figure 1.

In the colonies where mites were detected, the infestation levels were significantly higher in those containing European-derived morphotypes in the temperate sub-humid and temperate dry regions, and no differences were detected between the 2 morphotypes in the subtropical region. Additionally, significant effects of morphotype and region were found on the level of $V$. destructor infestation of colonies $\left(\mathrm{F}_{1.298}=7.5, \mathrm{P}<0.01 ; \mathrm{F}_{2.297}=19.6, \mathrm{P}<0.0001\right.$, 


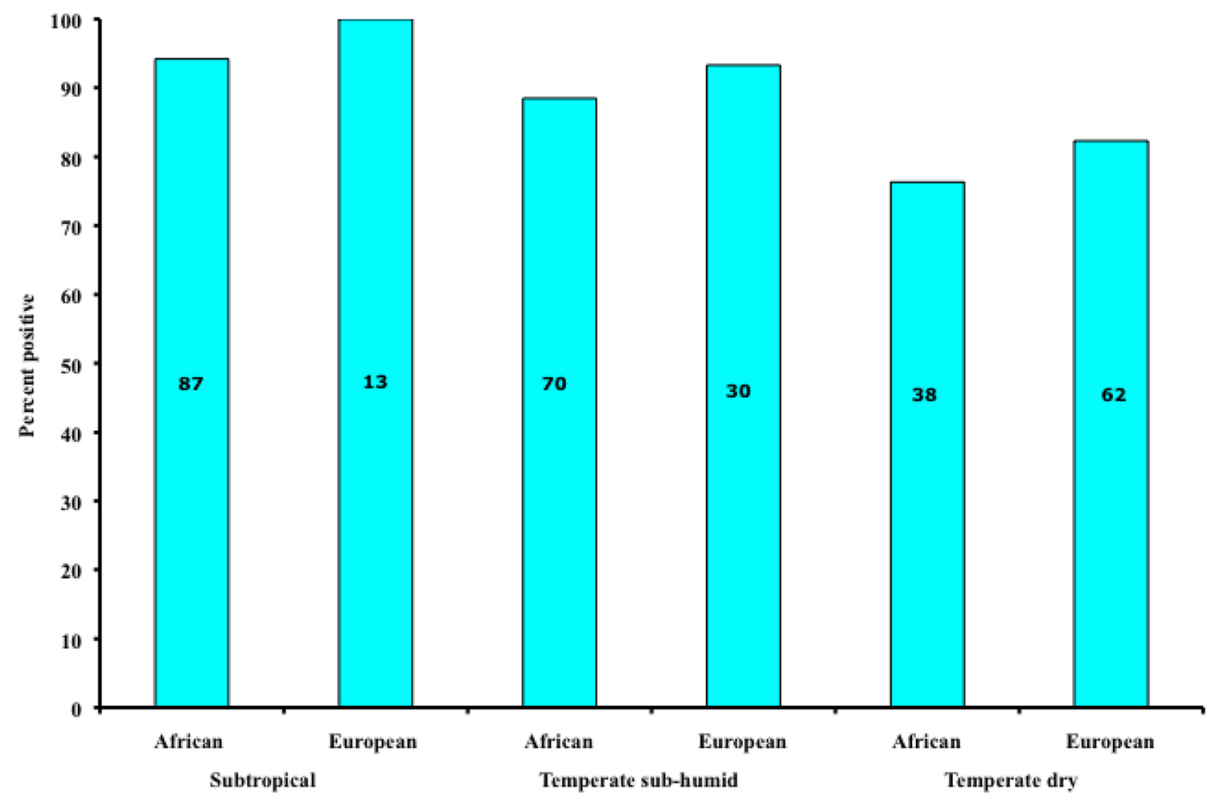

Figure 1. Percentage of honey bee colonies positive to Varroa destructor infestation on adult worker bees of African or European morphotype in subtropical, temperate sub-humid and temperate dry environments. Figures inside the bars correspond to numbers of colonies.

respectively), but no interaction effects between region and morphotypes were observed for this variable $(\mathrm{P}>0.05$; Figure 2$)$. When the data on Varroa infestation levels were analyzed just for mitotypes, no significant effects of mitotype or of mitotype $\mathrm{x}$ region were detected $(\mathrm{P}>0.05)$, but effects of region were significant $\left(\mathrm{F}_{2.294}=9.8, \mathrm{P}<0.0001\right)$. However, when paired comparisons between mitotypes were carried out for mite infestation levels, significantly higher levels of varroa mite infestation were observed in colonies with European mitotype than in colonies with African mitotype only in the temperate dry region $\left(\mathrm{t}_{50}=2.01, \mathrm{P}<0.05\right)$.

A total of 68 colonies had bees with both African morphotype and African mitotype, whereas 100 of them had both European morphotype and European mitotype. These 168 colonies with extreme "African" or "European" genotypes (morphotype plus mitotype) were subjected to further analyses to assess their association with $V$. destructor infestation levels and with amount of brood and bee populations in the 3 regions that were sampled. Again, colonies with African-derived genotypes showed lower levels of mite infestation than colonies with European-derived genotypes regardless of the region, and significant genotypic and region effects were detected $\left(\mathrm{F}_{1.166}=4.4, \mathrm{P}<0.05 ; \mathrm{F}_{2.165}=7.0, \mathrm{P}<0.01\right.$, respectively), although no interaction effects between genotype and region were found for this variable $(\mathrm{P}>0.05$; Figure 3$)$.

There were no genotypic differences in the number of brood combs per hive within regions, but colonies in the subtropical region had a significantly higher number of brood combs than colonies in the other 2 regions $(\mathrm{H}=21.2, \mathrm{P}<0.0001$; Table 3$)$. Regarding adult bee populations, there were no differences between genotypes or between regions $(\mathrm{P}>0.05)$. 


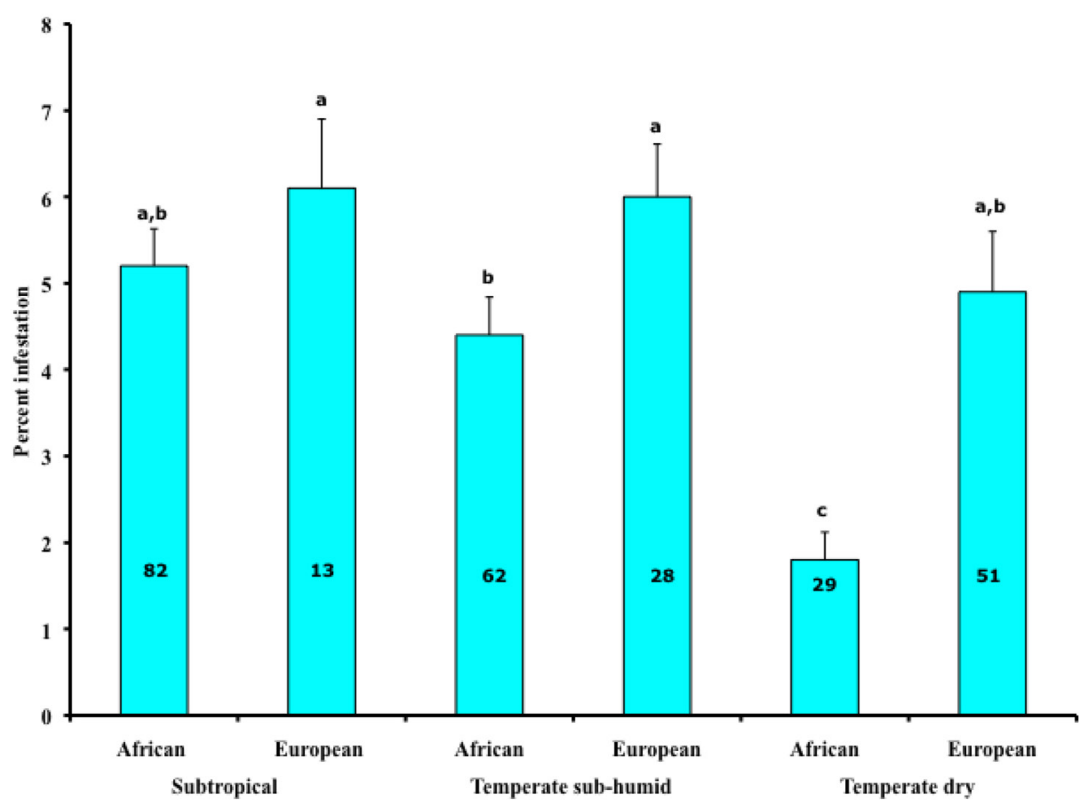

Figure 2. Percentage $( \pm \mathrm{SE})$ of worker honey bees of African or European morphotype infested with Varroa destructor in subtropical, temperate sub-humid and temperate dry environments. Figures inside the bars correspond to numbers of colonies. Different letters above the bars indicate significant differences of means based on ANOVA and protected LSD tests performed on arcsine-square-root transformed data. Depicted means and SE are actual nontransformed values.

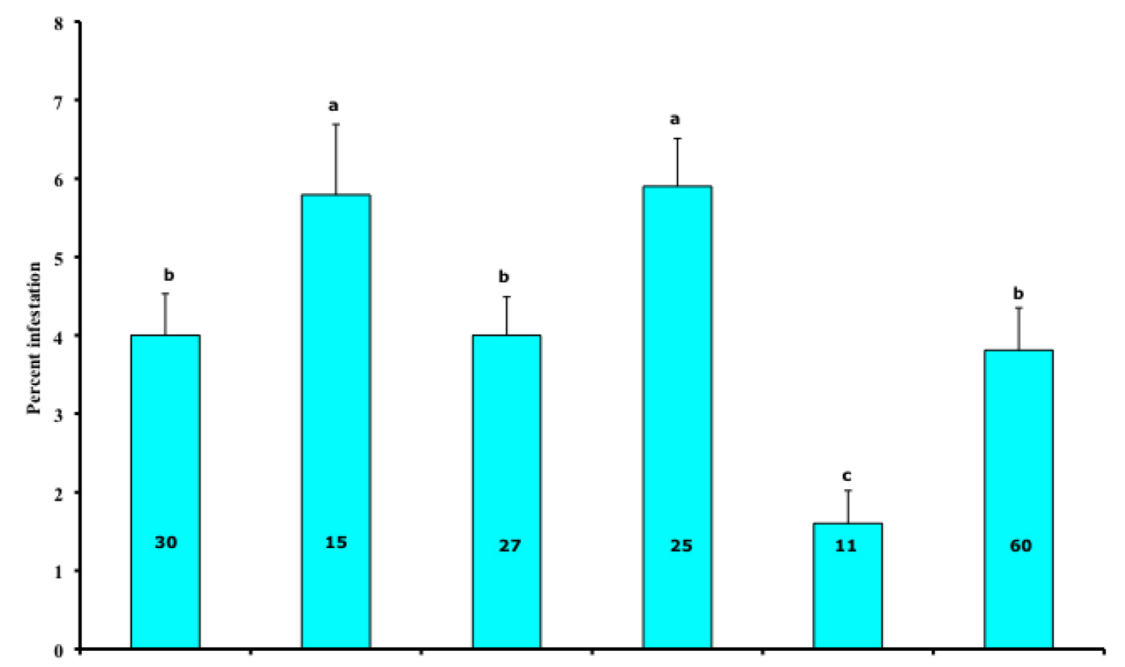

Figure 3. Percentage $( \pm \mathrm{SE})$ of worker honey bees of African or European genotype (morphotype plus mitotype) infested with Varroa destructor in subtropical, temperate sub-humid and temperate dry environments. Figures inside the bars correspond to numbers of colonies. Different letters above the bars indicate significant differences of means based on ANOVA and protected LSD tests performed on arcsine-square-root transformed data. Depicted means and SE are actual nontransformed values. 
Table 3. Mean number of frames of capped brood per colony $( \pm \mathrm{SE})$ for European- and African-derived genotypes (morphotype plus mitotype) in three different ecological regions of Mexico.

\begin{tabular}{lccc}
\hline Region & European genotype & African genotype & P U \\
\hline Subtropical & $5.5 \pm 0.50^{\mathrm{a}}(15)$ & $5.3 \pm 0.34^{\mathrm{a}}(30)$ & $\mathrm{ns}$ \\
Temperate sub-humid & $4.1 \pm 0.29^{\mathrm{b}}(25)$ & $3.9 \pm 0.36^{\mathrm{b}}(27)$ & $\mathrm{ns}$ \\
Temperate dry & $3.9 \pm 0.24^{\mathrm{b}}(60)$ & $3.4 \pm 0.72^{\mathrm{b}}(11)$ & $\mathrm{ns}$
\end{tabular}

Different letters indicate significant differences of means between regions within genotypes based on Kruskal Wallis and paired Mann-Whitney U-tests at a $\mathrm{P}<0.05$ for comparisons. Mann-Whitney U-tests were also used to compare genotypes within regions. Numbers in parentheses are numbers of colonies.

\section{DISCUSSION}

This is the first study that demonstrates the effects of Africanization and ecological environment on rates of infestation by $V$. destructor in honey bee colonies in North America. The proportion of colonies with bees of different morphotypes and mitotypes varied significantly between the study regions. A higher proportion of colonies with European-derived morphotypes or mitotypes were found in the temperate dry region than in the temperate sub-humid and subtropical regions, where higher frequencies of African-derived morphotypes and mitotypes were observed. These results indicate a higher degree of Africanization in colonies of the subtropical and temperate sub-humid areas and a lower degree of Africanization in colonies of the temperate dry area, suggesting environmental effects on African gene introgression in commercial colonies of honey bees.

The differences in the frequency of colonies with predominantly European or African ancestry between regions may have resulted, at least in part, from differences in climate and availability of floral resources and nesting sites in the areas. In the temperate dry region that we studied, blossoms are scarcer, colder temperatures reduce colony reproduction during winter, and its vegetation provides fewer nesting sites than in subtropical regions. Thus, it is less likely for bee colonies to swarm frequently and to establish feral populations in temperate climates than in more tropical environments (Otis, 1991; Clarke et al., 2002). Tropical and subtropical regions are more favorable for African gene introgression into commercial colonies because Africanized bees are better adapted to these environments than are European-derived bees. They show greater ability to reproduce and spread in the tropics than their European counterparts (Schneider et al., 2004). The higher density of Africanized colonies of honey bees in tropical environments allows for increased mating of virgin queens from commercial colonies with African-derived drones (Rinderer and Hellmich, 1991). Additionally, a higher rate of usurpation of commercial colonies by Africanized bee swarms would be expected in tropical environments (Danka et al., 1992). In managed apiaries like those sampled, beekeepers had a European maternal bee lineage before the arrival of Africanized bees in Zacatecas. Therefore, most of the introgression of African genes in these populations may have occurred paternally, mainly through mating between virgin queens from commercial colonies and drones of African origin that were produced by feral colonies (Clarke et al., 2002). This Africanization process of commercial colonies would explain why more colonies were classified as Africanderived by morphometric analyses than by mitochondrial analysis, which only detects maternal inheritance.

$V$. destructor was more prevalent in colonies of European-derived morphotypes than in colonies of African-derived morphotypes in the 3 regions studied. Additionally, mite in- 
festation rates were consistently higher in colonies of European-derived morphotypes and genotypes than in colonies of African-derived morphotypes and genotypes, regardless of the region. These results strongly suggest that colonies of predominantly African descent are relatively less susceptible to Varroa infestations than colonies of predominantly European descent in a variety of environments. Evidence generated in South America is consistent with these results because Africanized bee colonies in Brazil have lower mite loads and presumably greater tolerance to varroa mites than bees of European descent in different climates (De Jong et al., 1984; Moretto et al., 1991).

Low rates of mite infestation in African-derived honey bee colonies have been associated with a number of factors, including high swarming and migratory behavior (Otis, 1991), high levels of expression of hygienic behavior (Guerra Jr. et al., 2000; Vandame et al., 2002) or grooming behavior (Moretto et al., 1993, 1997; Arechavaleta-Velasco and Guzmán-Novoa, 2001; Guzmán-Novoa et al., 2012), reduced susceptibility to mite invasion and reproduction (Ritter and De Jong, 1984; Guzmán-Novoa et al., 1996; Medina and Martin, 1999; Mondragón et al., 2006), reduced cell size (Message and Gonçalves, 1995; Piccirillo and De Jong, 2003), and other factors of less relevance.

The growth of varroa mite populations in honey bee colonies is influenced by a number of factors, among which, the amount of brood available for their reproduction plays a major role (Fries et al., 1994). Brood rearing in colonies largely depends on the availability of pollen and nectar. Thus, brood rearing and mite reproduction are influenced by environmental conditions such as climate and food availability. It is likely that this is one of the reasons why higher Varroa infestation rates were detected in the subtropical and temperate sub-humid regions than in the temperate dry region. Less resources and a colder environment in the temperate dry region may have resulted in a smaller amount of brood in the colonies and consequently in lower chances for the mites to reproduce in this region.

The fact that higher rates of mite infestation were found in the subtropical and temperate humid regions than in the colder, temperate dry region was unexpected because it was reported that mite infestation levels in Africanized bee colonies are lower in Brazil's tropical environments than in temperate climates (De Jong et al., 1984; Moretto et al., 1991). Differences in mite fertility rates could offer a plausible partial explanation for these differences in mite rates for tropical and temperate climates that are reported in this study and in studies conducted in Brazil. Guzmán-Novoa et al. (1999) reviewed the evidence of several studies conducted in Mexico regarding the susceptibility of Africanized and European bees to the varroa mites and compared it with evidence generated in Brazil. The most striking difference between data from Brazil and those from Mexico was that mite fertility rates in Brazil are much lower than those reported in Mexico. Lower mite fertility rates would explain, at least in part, why Varroa infestation levels of colonies are low in Brazil's tropical environments. Theoretically, tropical environments would favor Varroa population growth because colonies of honey bees have brood all year long, which allows the mites to reproduce continuously. Conversely, in temperate climates, brood production is more seasonal, and mites reproduce mainly during times of brood abundance and less during winter. If mites reproduce at the same rate on the brood of bees from African and European descent (which seems to be the case in Mexico; see Guzmán-Novoa et al., 1999), this would result in higher mite infestation rates in tropical environments, which was observed in this study. In Brazil, however, less than $60 \%$ of the mites are able to reproduce in Africanized bee brood; thus, mite levels are low in tropical environments 
despite the fact that there is brood available year-round. In the study by Moretto et al. (1991), it is also possible that mite infestation rates of colonies in the temperate environment were overestimated in adult bees, presumably as a consequence of less brood being present during the colder months of the year, which would have increased mite levels in workers.

The results of this study represent the first evidence of variation in susceptibility to Varroa infestation between colonies of predominantly African and European descent in different climatic regions of North America. Vandame et al. (2000) conducted a study in which 20 colonies of 2 bee types were compared for varroa mite infestation rates in a tropical region of Mexico, and they found lower rates of infestation in colonies of bees that were classified as Africanized than in colonies of bees that were classified as European. However, Vandame et al. (2000) evaluated their colonies in only one environment.

Regardless of the specific climatic components and mechanisms of tolerance that interact to maintain lower mite infestation rates in populations of African-derived honey bees than in European bee populations, the evidence presented in this study supports the notion that North American honey bee colonies of African descent maintain lower Varroa infestation levels than colonies of European descent in a variety of ecological environments. These results support the hypothesis that Africanized bees in North America have not lost their preadaptation to resist varroa mite infestations, although the mechanisms of tolerance against the mite may be different than those of Africanized bees in Brazil. Additional studies are needed to further investigate the underlying environmental and genotypic components that allow Africanized bees in North America to maintain low varroa mite infestations in their colonies.

\section{ACKNOWLEDGMENTS}

We thank Laura G. Espinosa, José L. Uribe, and Ramón Gutiérrez for their valuable suggestions on an earlier version of the manuscript. Research suported partially by the NSERC Canada.

\section{REFERENCES}

Arechavaleta-Velasco ME and Guzmán-Novoa E (2000). Honey production with fluvalinate-treated and untreated honey bee (Apis mellifera L.) colonies in Valle de Bravo, Mexico. Veterinaria Mexic. 30: 381-384.

Arechavaleta-Velasco ME and Guzmán-Novoa E (2001). Relative effect of four characteristics that restrain the population growth of the mite Varroa destructor in honey bee (Apis mellifera) colonies. Apidologie 32: 157-174.

Chihu AD, Rojas LM and Rodríguez SR (1992). Primer reporte en México del ácaro Varroa jacobsoni, causante de la varroasis de la abeja melífera (Apis mellifera L.). Memorias VI Sem. Am. Apic. Oaxtepec Mexic. 9: 11.

Clarke KE, Rinderer TE, Franck P, Quezada-Euan JG, et al. (2002). The Africanization of honeybees (Apis mellifera L.) of the Yucatan: a study of a massive hybridization event across time. Evolution 56: 1462-1474.

Danka RG, Hellmich RL and Rinderer TE (1992). Nest usurpation, supersedure and colony failure contribute to Africanization of commercially managed European honey bees in Venezuela. J. Apic. Res. 31: 119-123.

De Jong D (1997). Mites: Varroa and Other Parasites of Brood. In: Honey Bee Pests, Predators and Diseases (Morse RA and Flottum K, eds.). AI Root Co., Medina, 279-328.

De Jong D, Roma DA and Gonçalves LS (1982). A comparative analysis of shaking solutions for the detection of Varroa jacobsoni on adult honeybees. Apidologie 13: 297-306.

De Jong D, Gonçalves LS and Morse RA (1984). Dependence on climate of the virulence of Varroa jacobsoni. Bee World 65: $117-121$.

Delaplane KS, van der Steen J and Guzmán-Novoa E (2013). Standard methods for estimating strength parameters of Apis mellifera colonies. J. Apic. Res. 52: 1-12. 
Fries I, Camazine S and Sneyd J (1994). Population dynamics of Varroa jacobsoni: a model and a review. Bee World 75: 5-28.

Guerra JCV Jr, Gonçalves LS and De Jong D (2000). Africanized honey bees (Apis mellifera L.) are efficient at removing worker brood artificially infested with the parasitic mite Varroa jacobsoni Oudemans than are Italian bees or Italian/ Africanized hybrids. Genet. Mol. Biol. 23: 89-92.

Guzmán-Novoa E, Sánchez A, Page RE and García T (1996). Susceptibility of European and Africanized honeybees (Apis mellifera L.) and their hybrids to Varroa jacobsoni Oud. Apidologie 27: 93-103.

Guzmán-Novoa E, Vandame R and Arechavaleta ME (1999). Susceptibility of European and Africanized honey bees (Apis mellifera L.) to Varroa jacobsoni Oud. in Mexico. Apidologie 30: 173-182.

Guzmán-Novoa E, Eccles L, Calvete Y, McGowan J, et al. (2010). Varroa destructor is the main culprit for the death and reduced populations of overwintered honey bee (Apis mellifera) colonies in Ontario, Canada. Apidologie 41: $443-450$.

Guzmán-Novoa E, Correa Benítez A, Espinosa Montaño LG and Guzmán Novoa G (2011). Colonization, impact and control of Africanized honey bees in Mexico. Veterinaria Mexic. 42: 149-178.

Guzmán-Novoa E, Emsen B, Unger P, Espinosa-Montano LG, et al. (2012). Genotypic variability and relationships between mite infestation levels, mite damage, grooming intensity, and removal of Varroa destructor mites in selected strains of worker honey bees (Apis mellifera L.). J. Invertebr. Pathol. 110: 314-320.

Instituto Nacional de Estadística Geografía e Informática - INEGI (2001). Municipios de Zacatecas. INEGI, Mexico DF, 234-235.

Le Conte Y, Ellis M and Ritter W (2010). Varroa mites and honey bee health: can Varroa explain part of the colony losses? Apidologie 41: 353-363.

Medina ML and Martin SJ (1999). A comparative study of Varroa jacobsoni reproduction in worker cells of honey bees (Apis mellifera) in England and Africanized bees in Yucatan, Mexico. Exp. Appl. Acarol. 23: 659-667.

Medina-Flores CA, Guzmán-Novoa E, Aréchiga-Flores CF, Aguilera-Soto JI, et al. (2011). Effect of Varroa destructor infestations on honey yields of Apis mellifera colonies in Mexico's semi-arid high plateau. Rev. Mexic. Cienc. Pecu. 2: 313-317.

Message D and Gonçalves LS (1995). Effect of size of worker brood cells of Africanized honey bees on infestation and reproduction of the ectoparasitic mite Varroa jacobsoni. Apidologie 26: 381-386.

Mondragón L, Martin S and Vandame R (2006). Mortality of mite offspring: a major component of Varroa destructor resistance in a population of Africanized bees. Apidologie 37: 67-74.

Moretto G and Mello Jr LJ (1999). Varroa jacobsoni infestation of adult Africanized and Italian honey bees (Apis mellifera) in mixed colonies in Brazil. Genet. Mol. Biol. 22: 321-323.

Moretto G, Gonçalves LS, De Jong D and Bichuette MZ (1991). The effects of climate and bee race on Varroa jacobsoni Oud infestations in Brazil. Apidologie 22: 197-203.

Moretto G, Gonçalves LS and De Jong D (1993). Heritability of Africanized and European honey bee defensive behavior against the mite Varroa jacobsoni. Rev. Bras. Genet. 16: 71-77.

Moretto G, Gonçalves LS and De Jong D (1997). Relationship between the infestation rate of Varroa jacobsoni in adult bees and the capacity of the workers to remove the mite from their bodies. Naturalia 22: 207-211.

Nielsen DI, Ebert P, Page RE, Hunt GJ, et al. (2000). Improved polymerase chain reaction-based mitochondrial genotype assay for identification of the Africanized honey bee (Hymenoptera: Apidae). Ann. Entomol. Soc. Am. 93: 1-6.

Otis GW (1991). Population Biology of the Africanized Honey Bee. In: The "African” Honey Bee (Spivak M, Fletcher DJC and Breed MD, eds.). Westview Press, Boulder, 213-234.

Page RE and Guzmán-Novoa E (1997). The Genetic Basis of Disease Resistance. In: Honey Bee Pests, Predators and Diseases (Morse RA and Flottum K, eds.). AI Root Co., Medina, 469-492.

Piccirillo GA and De Jong D (2003). The influence of brood comb cell size on the reproductive behavior of the ectoparasitic mite Varroa destructor in Africanized honey bee colonies. Genet. Mol. Res. 2: 36-42.

Quezada-Euán JJG (2000). Hybridization between European and Africanized honeybees in tropical Yucatan, Mexico. II. Morphometric, allozymic and mitochondrial DNA variability in feral colonies. Apidologie 31: 443-453.

Quezada-Euán JJG (2007). A retrospective history of the expansion of Africanized honeybees in Mexico. J. Apic. Res. 46: 295-300.

Rinderer TE and Hellmich RL (1991). The Process of Africanization. In: The “African” Honey Bee (Spivak M, Fletcher DJC and Breed MD, eds.). Westview Press, Boulder, 95-117.

Ritter W and De Jong D (1984). Reproduction of Varroa jacobsoni Oud. in Europe, the middle east and tropical South America. Z. Angew. Entomol. 98: 55-57.

Schneider SS, DeGrandi-Hoffman G and Smith DR (2004). The African honey bee: factors contributing to a successful 
biological invasion. Annu. Rev. Entomol. 49: 351-376.

Sylvester HA and Rinderer TE (1987). Fast Africanized Bee Identification System (FABIS) Manual. Am. Bee J. 127: 511-516.

Vandame R, Colin ME, Morand S and Otero-Colina G (2000). Levels of compatibility in a new host-parasite association: Apis mellifera/Varroa jacobsoni. Can. J. Zool. 78: 2037-2044.

Vandame R, Morand S, Colin ME and Belzunces LP (2002). Parasitism in the social bee Apis mellifera: quantifying costs and benefits of behavioral resistance to Varroa destructor mites. Apidologie 33: 432-445.

Winston ML (1992). The biology and management of Africanized honey bees. Ann. Rev. Entomol. 37: 173-193. 